\title{
Alkylation Reactions of Dialkylzinc Compounds with 1,4-Diaza-1,3-butadienes: Cationic and Radical Anionic Organozinc Intermediates. Molecular Structure of the Cationic Organozinc Species $[\operatorname{MeZn}(t-\mathrm{BuN}=\mathrm{CHCH}=\mathrm{N}-t-\mathrm{Bu})]_{3} \mathrm{SCF}_{3}$ and $\mathrm{Me}_{2} \mathrm{Zn}(\mathrm{bpy})$ (bpy $=2,2^{\prime}$-Bipyridine)
}

\author{
Elmo Wissing, ${ }^{\dagger}$ Martin Kaupp,$^{\ddagger}$ Jaap Boersma, ${ }^{\dagger}$ Anthony L. Spek,,${ }^{\S} \|$ and \\ Gerard van Koten ${ }^{*}, \dagger$ \\ Debye Institute, Department of Metal-Mediated Synthesis, Utrecht University, \\ Padualaan 8, 3584 CH Utrecht, The Netherlands, Max-Planck-Institut für \\ Festkörperforschung, Heisenbergstrasse 1, 70563 Stuttgart, FRG, and Bijvoet Center for \\ Biomolecular Research, Laboratory of Crystal and Structural Chemistry, Utrecht University, \\ Padualaan 8, 3584 CH Utrecht, The Netherlands
}

Received February 11, 1994

\begin{abstract}
1,4-Disubstituted 1,4-diaza-1,3-butadienes, $\mathrm{R}^{\prime} \mathrm{N}=\mathrm{CHCH}=\mathrm{NR}^{\prime}\left(\mathrm{R}^{\prime} \mathrm{DAB}\right)$, are regioselectively alkylated by $R_{2} \mathrm{Zn}$ compounds. It is suggested that the mechanism of these alkylation reactions involves prior formation of the $1: 1 R_{2} \operatorname{Zn}\left(R^{\prime} D A B\right)$ complex $(R=$ alkyl) followed by intramolecular ligand-to-ligand electron transfer, generating, via homolytic $\mathrm{R}-\mathrm{Zn}$ bond cleavage, a [RZn$\left.\left(\mathrm{R}^{\prime} \mathrm{DAB}\right)\right]^{*} / R^{\bullet}$ radical pair. Collapse of this latter pair results in the formation of $\mathrm{N}$ - or $\mathrm{C}$-alkylation products. In the present study one aspect of a possible polar mechanism is probed, for which organozinc radical anions $\left[R_{2} \mathrm{Zn}\left(\mathrm{R}^{\prime} \mathrm{DAB}\right)\right]^{*-}$ and organozinc cations $\left[R \mathrm{Rn}\left(\mathrm{R}^{\prime} \mathrm{DAB}\right)\right]^{+}$have been suggested as the key intermediates. Representative examples of such organozinc cations, i.e. the title compound [MeZn(t-BuDAB)]OTf (9) and [(2,6-xylyl) $\mathrm{Zn}(t$-BuDAB)]OTf (10), were separately prepared from their corresponding $1: 1$ coordination complexes $\mathrm{Me}_{2} \mathrm{Zn}(t-\mathrm{BuDAB})$ and $(2,6 \text {-xylyl })_{2} \mathrm{Zn}(t-\mathrm{BuDAB})$, respectively, by their reaction with 1 equiv of trifluoromethanesulfonic acid. The X-ray crystal structure of 9 shows a four-coordinate zinc atom with a distortedtetrahedral geometry, wherein the triflate is bonded almost perpendicular to the $\mathrm{MeZn}(t-\mathrm{BuDAB})$ plane. Structural parameters in the MeZn $(t-B u D A B)$ plane are in good agreement with ab initio results for the MeZn(H-DAB) cation. The X-ray crystal structure determination of $\mathrm{Me}_{2}-$ $\mathrm{Zn}$ (bpy) (1c; bpy = 2,2'-bipyridine) has been carried out to compare the structural features of two neutral complexes, e.g. $\mathrm{Me}_{2} \mathrm{Zn}$ (bpy) and $\mathrm{Me}_{2} \mathrm{Zn}(t$-BuDAB), with cationic species such as 9. ${ }^{19} \mathrm{~F}$ NMR spectra of $\mathbf{9}$ and 10 in benzene and tetrahydrofuran indicate that in solution the triflate-zinc bond dissociates to give the solvated cationic species $[R Z n(t-B u D A B)]^{+}(R=M e$, 2,6-xylyl). The title compound 9 reacts with 1-(trimethylsiloxy)-1-ethoxycyclopropane via $\mathrm{C}$-alkylation of the NCCN skeleton to give a 2-pyrrolidinone derivative (11). Crystal data: 1c, $\mathrm{C}_{12} \mathrm{H}_{14} \mathrm{~N}_{2} \mathrm{Zn}$, orthorhombic, Pbam (No. 55), $a=12.0547$ (8) $\AA, b=6.4374(4) \AA, c=7.8186$ (3) $\AA$, $V=606.73 \AA^{3}, Z=2, R=0.046 ; 9, \mathrm{C}_{12} \mathrm{H}_{23} \mathrm{~N}_{2} \mathrm{O}_{3} \mathrm{~F}_{3} \mathrm{SZn}$, monoclinic, $P 2_{1} / a$ (No. 14), $a=12.345(2)$ $\AA, b=11.363(2) \AA, c=13.260(3) \AA, \beta=108.33(2)^{\circ}, V=1765.7(6) \AA^{3}, Z=4, R=0.068$.
\end{abstract}

\section{Introduction}

Transformations involving paramagnetic species resulting from single-electron-transfer (SET) processes occur widely in metal-mediated organic synthesis. ${ }^{1}$ Stufkens and Oskam and co-workers ${ }^{2 \mathrm{a}}$ and Kaim and co-workers ${ }^{2 \mathrm{~b}, \mathrm{c}}$ have studied such species derived from main-groupelement complexes with bidentate ligands such as $2,2^{\prime}$ bipyridine (=bpy) and 1,10-phenanthroline. We have studied the intramolecular group transfer reaction of

* To whom correspondence should be addressed.

† Debye Institute, Utrecht University.

¥ Max-Planck-Institut fur Festkörperforschung.

I Bijvoet Center for Biomolecular Research.

\| Address correspondence regarding the crystallography to this author.

- Abstract published in Advance ACS Abstracts, April 15, 1994.

(1) (a) Kochi, J. K. Organometallic Mechanisms and Catalysis; Academic Press: New York, 1978. (b) Trögler, W. C., Ed. Organometallic Radical Processes; Elsevier: Amsterdam, 1990. (c) Ashby, E. C. Acc. Chem. Res. 1988, 21, 414.

(2) (a) Andrea, R. R.; de Lange, W. G. J.; van der Graaf, T.; Rijkhoff, M.; Stufkens, D. J.; Oskam, A. Organometallics 1988, 7, 1100 . (b) Kaim, W. Acc. Chem. Res. 1985, 18, 160. (c) Kaim, W.; Olbrich-Deussner, B. In ref $1 \mathrm{~b}, \mathrm{p} 173$. dialkylzinc compounds, $\mathrm{R}_{2} \mathrm{Zn}$, with 1,4-disubstituted 1,4diaza-1,3-butadienes $\left(\mathrm{R}^{\prime} \mathrm{N}=\mathrm{CHCH}=\mathrm{NR}^{\prime} ; \mathrm{R}^{\prime} \mathrm{DAB}\right)$ and found a regioselective alkylation reaction at either the imine carbon or imine nitrogen atom of the $\alpha$-diimine NCCN skeleton. On the basis of the products formed in the reaction of $\mathrm{R}_{2} \mathrm{Zn}$ with $\mathrm{R}^{\prime} \mathrm{N}=\mathrm{CH}-[2]-\mathrm{py}\left(\mathrm{R}^{\prime} \mathrm{Pyca} ; \mathrm{py}=\right.$ pyridine) we proposed an SET mechanism for the alkylation reaction of the $\alpha$-diimines $\mathrm{R}^{\prime} \mathrm{DAB}$ and $\mathrm{R}^{\prime}$ Pyca. This proposal has been used as a working hypothesis in our chemistry of $R_{2} \mathrm{Zn}$ reagents with $\mathrm{R}^{\prime} \mathrm{DAB}{ }^{3}$ The group

(3) (a) van Koten, G.; Jastrzebski, J. T. B. H.; Vrieze, K. J. Organomet. Chem. 1983, 250, 49. (b) Klerks, J. M.; Jastrzebski, J. T. B. H.; van Koten, G.; Vrieze, K. J. Organomet. Chem. 1982, 224, 107. (c) van Koten, G. In Organometallics in Organic Synthesis; de Meijere, A., tom Dieck, H., Eds.; Springer-Verlag: Berlin, 1987; p 277. (d) van Vliet, M. R. P.; van Koten, G.; Buysingh, P.; Jastrzebski, J. T. B. H.; Spek, A. L. Organometallics 1987, 6, 537. (e) van Vliet, M. R. P.; Jastrzebski, J. T. B. H.; Klaver, W. J.; Goubitz, K.; van Koten, G. Recl. Trav. Chim. PaysBas 1987, 106, 132. (f) van der Steen, F. H.; Kleijn, H.; Jastrzebski, J. T. B. H.; van Koten, G. J. Org. Chem. 1991, 56, 5147. (g) van der Steen, F. H.; Kleijn, H.; Spek, A. L.; van Koten, G. J. Org. Chem. 1991, 56, 5868 . (h) van der Steen, F. H.; Boersma, J.; Spek, A. L.; van Koten, G. Organometallics 1991, 10, 2467. 
Scheme 1

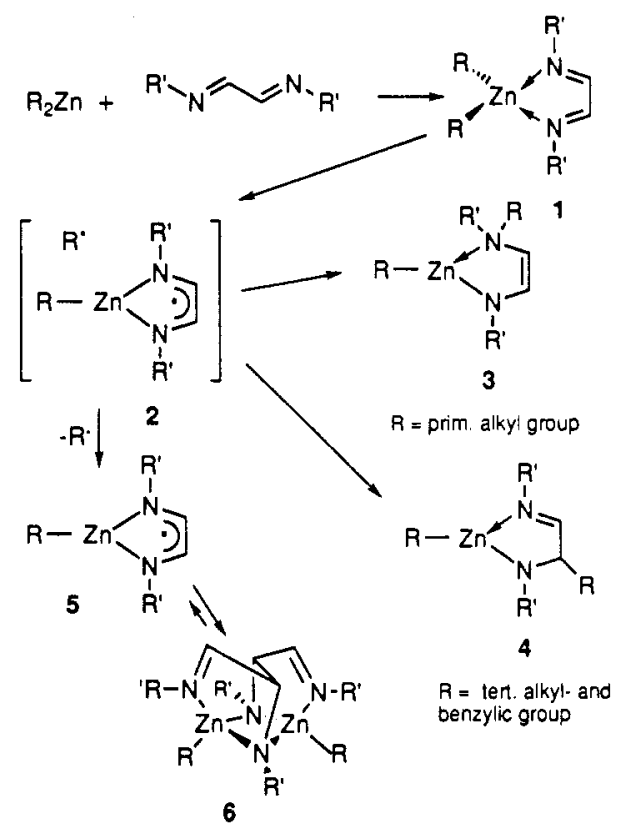

transfer reaction of $R_{2} \mathrm{Zn}$ with $\mathrm{R}^{\prime} \mathrm{DAB}$ starts with the initialformation of the 1:1 coordination complex $R_{2} \mathrm{Zn}$ $\left(\mathrm{R}^{\prime} \mathrm{DAB}\right)(1)$, which undergoes an intramolecular SET, ${ }^{4}$ leading to the $\left[R Z n\left(R^{\prime} D A B\right)\right]^{*} / R^{*}$ radical pair 2 . Subsequently, this radical pair has two possible transformation routes. In the first route there is collapse by alkylating the NCCN skeleton of the coordinated DAB ligand; this gives either the $\mathrm{N}$-alkylated product 3 , if $\mathrm{R}$ is a primary alkyl group, or the C-alkylated product 4 , when $R$ is a tertiary alkyl or benzylic group. In the second route the alkyl radical escapes from the solvent cage of the radical pair, leaving the organozinc radical 5 , which is in equilibrium with its C-C-coupled dimer 6 (see Scheme 1).

So far, evidence for possible alternative mechanisms has not been obtained. However, recently we detected by ESR the presence of the radical anionic organozinc species $\left[R_{2} \mathrm{Zn}\left(\mathrm{R}^{\prime} \mathrm{DAB}\right)\right]^{\cdot-}(7)$ in the reaction mixtures. ${ }^{4}$ This unexpected observation prompted us to investigate the formation of this species as well as that of the organozinc cationic species $\left[R Z n\left(R^{\prime} D A B\right)\right]^{+}$, which would be an obvious counterion for 7 . Although several examples of ionic organomagnesium complexes have been described, ${ }^{5-7}$ few reports on ionic organozinc species have appeared. Only a few zincate species with ionic structure $\mathrm{R}_{3} \mathrm{Zn}^{-} \mathrm{X}^{+}$ have been isolated, ${ }^{5 c, d, g, h}$ although their existence in solution has often been suggested. ${ }^{8}$ Nibler and Cook have reported the cationic organozinc species $\mathrm{MeZn}^{+} \mathrm{BH}_{4}{ }^{-}$and produced evidence for a $\mathrm{MeZn}^{+}$ion which interacts with $\mathrm{BH}_{4}{ }^{-9}$ Further, cationic [RZn(cryptand) ]+ species have

(4) Kaupp, M.; Stoll, H.; Preuss, H.; Kaim, W.; Stahl, T.; van Koten, G.; Wissing, E.; Smeets, W. J. J.; Spek, A. L. J. Am. Chem. Soc. 1991, 113, 5606.

(5) (a) Ashby, E. C.; Beach, R. G. Inorg. Chem. 1971, 10, 2486. (b) Ashby, E. C.; Watkins, J. J. Inorg. Chem. 1973, 12, 2493. (c) Weiss, E. Wolfrum, R. Chem. Ber. 1968, 101, 35. (d) Weiss, E.; Plass, H. J. Organomet. Chem. 1968, 14, 21. (e) Habeeb, J. J.; Osman, A.; Tuck, D. G. J. Organomet. Chem. 1980, 185, 117. (f) Fabicon, R. M.; Pajerski, A. D.; Richey, H. D., Jr. J. Am. Chem. Soc. 1991, 113, 6680. (g) Fabicon, R. M.; Parver, M.; Richey, H. D., Jr. J. Am. Chem. Soc. 1991, 113, 1412. (h) Purdy, A. P.; George, C. F. Organometallics 1992, 11, 1955.

(6) Markies, P. R.; Nomoto, T.; Akkerman, O. S.; Bickelhaupt, F. J. Am. Chem. Soc. 1988, 110, 4845.

(7) (a) Squiller, E. P.; Whittle, R. R.; Richey, H. G., Jr. J. Am. Chem. Soc. 1985, 107, 432. (b) Pajerski, A. D.; Parvez, M.; Richey, H. D., Jr. J. Am. Chem. Soc. 1988, 110, 2660. been detected in solution with ${ }^{1} \mathrm{H}$ and ${ }^{13} \mathrm{C}$ NMR spectroscopy, though no structural evidence has yet been reported.5f Recently we succeeded in the isolation and characterization of [(benzyl $\left.)_{3} \mathrm{Zn}\right]_{2}\left[\mathrm{Mg}(\mathrm{THF})_{6}\right]$ both in the solid state and in solution. ${ }^{10}$

In this paper we describe the synthesis and characterization of the cationic species [RZn $(t-B u D A B)] O T f(R=$ $\mathrm{Me}(9), 2,6$-xylyl (10)) in solution, as well as the structure of 9 in the solid state. $\mathrm{Me}_{2} \mathrm{Zn}$ (bpy) (1c) has been prepared and its structure in the solid state determined to study the Me-to-bpy electronic interplay and to compare it with that in $\mathrm{Me}_{2} \mathrm{Zn}(t-\mathrm{BuDAB})$. On the basis of these new findings and the recently reported organozinc radical anionic species $\left[R_{2} Z n\left(R^{\prime} D A B\right)\right]^{--}(7)$, an alternative mechanism for the alkylation reaction of $R_{2} Z n$ with $R^{\prime} D A B$ will be discussed. $A b$ initio structure optimizations on the free $\mathrm{MeZn}(\mathrm{H}-\mathrm{DAB})$ cation and the radical cations of the recombination products have been carried out to obtain additional information on these possible intermediates.

\section{Results}

The organozinc complexes [RZn $(t-B u D A B)] O T f(R=$ $\mathrm{Me}$ (9), 2,6-xylyl (10)) are easily prepared from the reaction of the corresponding $\mathrm{R}_{2} \mathrm{Zn}(t-\mathrm{BuDAB})(\mathrm{R}=\mathrm{Me}$ (1a), 2,6xylyl (1b)) coordination complexes with 1 equiv of trifluoromethanesulfonic acid (HOTf). The best results in the synthesis of $[\mathrm{MeZn}(t-\mathrm{BuDAB})] \mathrm{OTf}(9)$ were obtained when a solution of $1 \mathrm{a}$ in diethyl ether was added to a solution of HOTf in diethyl ether. This procedure affords the off-white complex 9 , as a solid which is only slightly soluble in organic solvents such as diethyl ether, hexane, and tetrahydrofuran. The first step in the reaction is the formation of the inorganic coordination complex $(\mathrm{OTf})_{2} \mathrm{Zn}$ $(t-\mathrm{BuDAB})$, which in a subsequent disproportionation reaction with la gives 9 (see eq 1 ). The synthesis of 10 requires the reverse addition, i.e. HOTf to $1 \mathbf{b}$, because of the very low solubility of the latter (see eq 2 ).

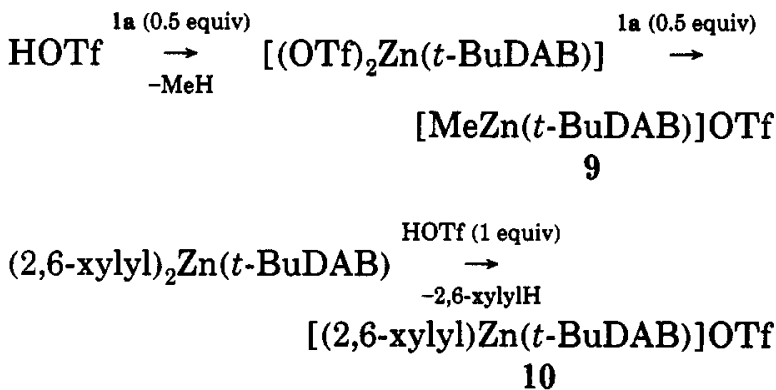

Since the trifluoromethanesulfonate anion $\mathrm{CF}_{3} \mathrm{SO}_{3}{ }^{-}$is known for its low coordinating ability and lack of nucleophilic character, it seemed likely that 9 and 10 were new three-coordinate cationic organozinc species. To establish their molecular structures and to gain information about the coordination geometry of the zinc atom, an $\mathrm{X}$-ray structure determination of 9 was carried out. Figure 1 presents a picture of the molecule, while selected bond

(8) (a) Nützel, K. Methoden Org. Chem. (Houben-Weyl), 4th Ed.1973, 13 (Part 2a), 553. (b) Isobe, M.; Kondo, S.; Nagasawa, N.; Goto, T. Chem. Lett. 1977, 679. (c) Langer, W.; Seebach, D. Helv. Chim. Acta 1979, 62, 1710. (d) Watson, R. A.; Kjonaas, R. A. Tetrahedron Lett. 1986, 27, 1437. (e) Kjonaas, R. A.; Vawter, E. J. J. Org. Chem. 1986, 51, 3993. (f) Tückmantal, W.; Oshima, K.; Nozaki, H. Chem. Ber. 1986, 119, 1581. (g) Hanawalt, E. M.; Richey, H. G., Jr. J. Am. Chem. Soc. 1990, 112, 4983.

(9) Nibler, J. W.; Cook, T. H. J. Chem. Phys. 1973, 58, 1596.

(10) Rijnberg, E.; Boersma, J.; van Koten, G. To be submitted for publication. 


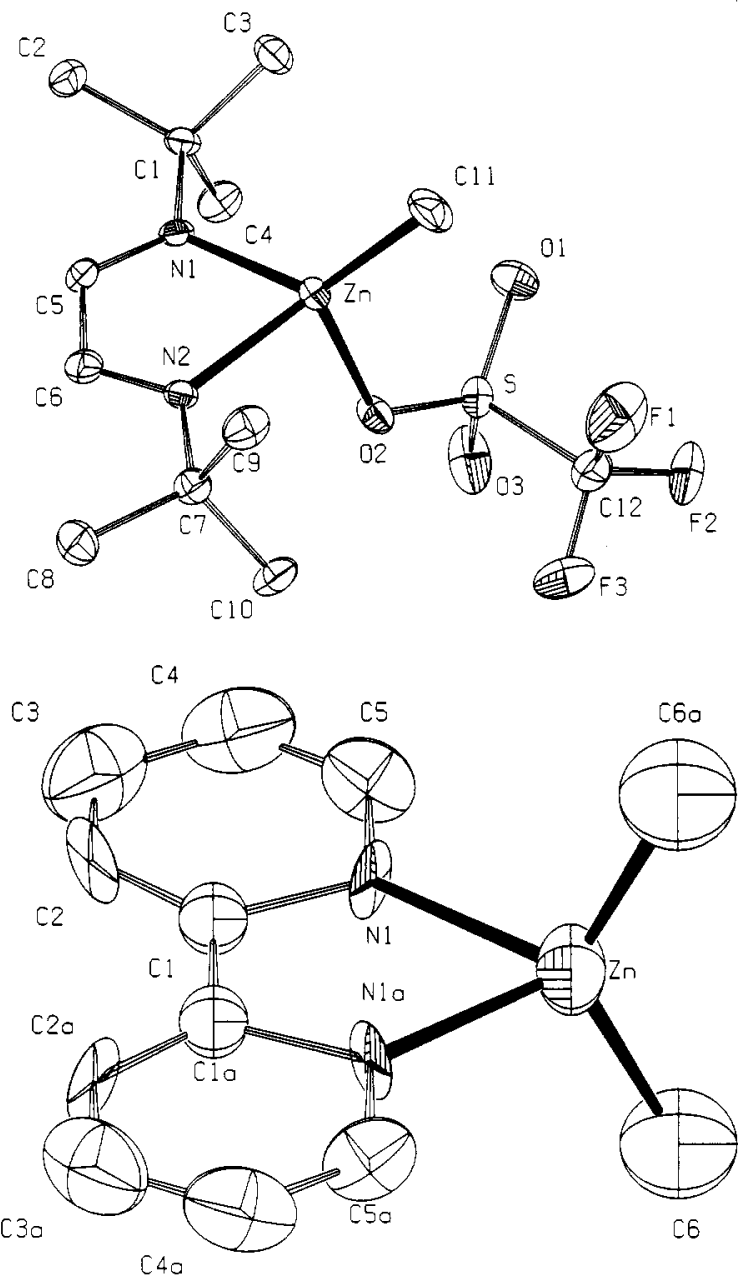

Figure 1. ORTEP drawings (drawn at the 50\% probability level) of the molecular structures of (a, top) [MeZn( $t$ $\mathrm{BuN}=\mathrm{CH}-\mathrm{CH}=\mathrm{N}-t-\mathrm{Bu}) \mathrm{O}_{3} \mathrm{SCF}_{3}(9)$ and $\left(\mathrm{b}\right.$, bottom) $\mathrm{Me}_{2}-$ $\mathrm{Zn}$ (bpy) (1c), with their adopted numbering schemes.

Table 1. Selected Bond Lengths $(\AA)$ and Bond Angles (deg) with Esd's in Parentheses

\begin{tabular}{lccc}
\hline \multicolumn{5}{c}{ (a) Compound 9 } \\
\multicolumn{5}{c}{ Bond Lengths } \\
$\mathrm{Zn}-\mathrm{N}(1)$ & $2.098(4)$ & $\mathrm{N}(2)-\mathrm{C}(6)$ & $1.271(7)$ \\
$\mathrm{Zn}-\mathrm{N}(2)$ & $2.088(5)$ & $\mathrm{C}(5)-\mathrm{C}(6)$ & $1.475(7)$ \\
$\mathrm{Zn}-\mathrm{C}(11)$ & $1.958(6)$ & $\mathrm{S}-\mathrm{O}(1)$ & $1.433(5)$ \\
$\mathrm{Zn}-\mathrm{O}(2)$ & $2.089(4)$ & $\mathrm{S}-\mathrm{O}(2)$ & $1.474(4)$ \\
$\mathrm{N}(1)-\mathrm{C}(5)$ & $1.264(8)$ & $\mathrm{S}-\mathrm{O}(3)$ & $1.428(4)$ \\
\multicolumn{5}{c}{} \\
$\mathrm{O}(2)-\mathrm{Zn}-\mathrm{C}(11)$ & $116.8(2)$ & $\mathrm{Zn}-\mathrm{N}(1)-\mathrm{C}(5)$ & $111.3(3)$ \\
$\mathrm{O}(2)-\mathrm{Zn}-\mathrm{N}(1)$ & $96.95(16)$ & $\mathrm{Zn}-\mathrm{N}(2)-\mathrm{C}(6)$ & $112.0(4)$ \\
$\mathrm{O}(2)-\mathrm{Zn}-\mathrm{N}(2)$ & $96.21(17)$ & $\mathrm{Zn}-\mathrm{O}(2)-\mathrm{S}$ & $124.3(2)$ \\
$\mathrm{C}(11)-\mathrm{Zn}-\mathrm{N}(1)$ & $130.4(2)$ & $\mathrm{O}(2)-\mathrm{S}-\mathrm{C}(12)$ & $103.5(3)$ \\
$\mathrm{C}(11)-\mathrm{Zn}-\mathrm{N}(2)$ & $127.1(2)$ & $\mathrm{N}(1)-\mathrm{C}(5)-\mathrm{C}(6)$ & $118.8(5)$ \\
$\mathrm{N}(1)-\mathrm{Zn}-\mathrm{N}(2)$ & $79.56(17)$ & $\mathrm{N}(2)-\mathrm{C}(6)-\mathrm{C}(5)$ & $117.8(5)$
\end{tabular}

\begin{tabular}{clll}
\multicolumn{5}{c}{ (b) Compound 1c } \\
$\mathrm{Zn}-\mathrm{N}(1)$ & $2.116(9)$ & $\mathrm{N}(1)-\mathrm{C}(1)$ & $1.429(8)$ \\
$\mathrm{Zn}-\mathrm{C}(6)$ & $2.056(5)$ & $\mathrm{C}(1)-\mathrm{C}(1 \mathrm{a})$ & $1.464(5)$ \\
\multicolumn{5}{c}{} \\
$\mathrm{C}(6)-\mathrm{Zn}-\mathrm{C}(6 \mathrm{a})$ & $127.96(10)$ & $\mathrm{Zn}-\mathrm{N}(1)-\mathrm{C}(1)$ & $120.4(7)$ \\
$\mathrm{N}(1)-\mathrm{Zn}-\mathrm{C}(6)$ & $109.5(3)$ & $\mathrm{Zn}-\mathrm{N}(1)-\mathrm{C}(5)$ & $127.8(14)$ \\
$\mathrm{N}(1)-\mathrm{Zn}-\mathrm{C}(6 \mathrm{a})$ & $111.5(4)$ & $\mathrm{N}(1)-\mathrm{Zn}-\mathrm{N}(1 \mathrm{a})$ & $74.3(6)$
\end{tabular}

distances and angles for 9 are listed in Table 1 . The structure of 9 in the solid state contains a four-coordinate zinc atom, which has a severely distorted tetrahedral geometry. This zinc atom is surrounded by a Me group, the triflate anion, and the chelate-bonded $D A B$ ligand
Table 2. Hartree-Fock Optimized Internal Coordinates of the Cation [MeZn(HDAB $]^{+}, b$ the radical $[\operatorname{MeZn}(\mathrm{HDAB})]^{\circ}$, and $\mathrm{Me}_{2} \mathrm{Zn}(\mathrm{HDAB})$

\begin{tabular}{cccccccc}
\hline complex & $\mathrm{Me}-\mathrm{Zn}^{d}$ & $\mathrm{Zn}-\mathrm{N}^{d}$ & $\mathrm{~N}-\mathrm{C}$ & $\mathrm{C}-\mathrm{C}$ & $\angle \mathrm{N}-\mathrm{Zn}-\mathrm{N}$ & $\angle \mathrm{N}-\mathrm{C}-\mathrm{C}$ \\
\hline [MeZn(HDAB)] $^{+}$ & 1.97 & 2.12 & 1.26 & 1.49 & 77 & 117 \\
[MeZn(HDAB)] $^{-}$ & 1.97 & 1.98 & 1.32 & 1.41 & 83 & 117 \\
$\mathrm{Me}_{2} \mathrm{Zn}(\mathrm{HDAB})^{c}$ & 2.03 & 2.33 & 1.25 & 1.47 & 70 & 118
\end{tabular}

${ }^{a}$ Bond lengths in ångstroms and bond angles in degrees. ${ }^{b}$ See Table 1 for the observed data of $[\mathrm{MeZn}(t-\mathrm{BuDAB})]^{+} \mathrm{OTf}^{-}(9)$. ${ }^{c}$ See ref $4 a$. ${ }^{d}$ For the experimental bond lengths in the $1: 1$ complexes $\mathrm{Me}_{2} \mathrm{Zn}(t$ BuDAB) (1a) and $\mathrm{Me}_{2} \mathrm{Zn}$ (bpy) (1c), see Table 4 .

with a N-Zn-N bite angle of $79.56(17)^{\circ}$. The triflate anion is bonded in a monodentate fashion via a $\mathrm{Zn}-0$ bond of 2.089 (4) $\AA$. The bond between this oxygen and the central sulfur atom ( $\mathrm{S}-\mathrm{O}(2)=1.474(4) \AA$ ) is slightly longer than the other two $\mathrm{S}-\mathrm{O}$ bonds of the terminal oxygens (1.433(5) $\AA$ for $\mathrm{S}-\mathrm{O}(1)$ and $1.428(4) \AA$ for $\mathrm{S}-\mathrm{O}(3)$ ), in accord with their double-bond character. The five-membered chelate ring $\mathrm{ZnNCCN}$ is almost planar, with a torsion angle of $3.4(8)^{\circ}$ and $\mathrm{N}-\mathrm{Zn}$ bond distances of 2.098(4) and 2.088(5) $\AA$. The angles made by the $\mathrm{Me}-\mathrm{Zn}$ and $\left(\mathrm{CF}_{3} \mathrm{SO}_{2}\right) \mathrm{O}-\mathrm{Zn}$ bonds with this plane are 130.4 and $96.9^{\circ}$, illustrating the severe distortion of the tetrahedral surrounding of the zinc atom. To be able to evaluate these points further, the X-ray crystal structure of $\mathrm{Me}_{2} \mathrm{Zn}$ (bpy) (1c) was also determined. This showed that $1 \mathrm{c}$ has a totally symmetric structure (see Figure 1b) in which the bpy ligand is bidentate $\mathrm{N}, \mathrm{N}^{\prime}$-bonded to the zinc atom with $\mathrm{Zn}-\mathrm{N}$ bond lengths of 2.116(9) $\AA$ and a N-Zn-N bond angle of 74.3$(6)^{\circ}$. The $\mathrm{Zn}-\mathrm{C}$ bond lengths and $\mathrm{C}-\mathrm{Zn}-\mathrm{C}$ bond angles are 2.056(5) $\AA$ and $127.96(10)^{\circ}$, respectively. Selected bond distances and angles for 1c are listed in Table $1 \mathrm{~b}$.

Although the X-ray crystal structure of 9 did not show the expected planar three-coordinate zinc atom, a planar geometry was found in our Hartree-Fock geometry optimizations (within $C_{s}$ symmetry) for the model cationic species $[\mathrm{MeZn}(\mathrm{HDAB})]^{+}(\mathrm{HDAB}=\mathrm{HN}=\mathrm{CHCH}=\mathrm{NH})$. The calculated bond lengths and angles are listed in Table 2 , together with data reported earlier for the organozinc radical $[\mathrm{MeZn}(\mathrm{HDAB})]^{*}$ and the primary $1: 1$ coordination complex $\mathrm{Me}_{2} \mathrm{Zn}(\mathrm{HDAB}){ }^{4}$ The $\mathrm{Zn}-\mathrm{N}$ and $\mathrm{C}-\mathrm{C}$ bonds in the cationic species are considerably elongated relative to those found in the neutral radical [MeZn(HDAB)]', whereas the $\mathrm{N}=\mathrm{C}$ bonds are shorter. The SOMO of the latter corresponds to the $\pi^{*}$ MO of DAB, which is the LUMO of the primary 1:1 coordination complex $\mathrm{Me}_{2} \mathrm{Zn}$ (HDAB) ${ }^{4}$ Thus, removal of an electron from the neutral radical results in the cationic species having a HOMO level with the same symmetry as the HOMO of the coordination complex $\mathrm{Me}_{2} \mathrm{Zn}$ (HDAB); accordingly, similar $\mathrm{N}=\mathrm{C}$ and $\mathrm{C}-\mathrm{C}$ bond distances were found. Finally, the $\mathrm{MeZn}^{+}$character of the metal unit in [MeZn(HDAB) ${ }^{+}$ results in $\mathrm{Zn}-\mathrm{N}$ distances that are very short compared to those in the coordination complex.

Cationic organozinc complexes such as these may be considered as intermediates in the alkylation reactions of dialkylzinc compounds with $R^{\prime} D A B$. An essential step in these reactions could be the alkylation of the organozinc$\mathrm{R}^{\prime} \mathrm{DAB}$ cationic species by an alkyl radical to give the radical cationic organozinc species [RZn(alkylated $\mathrm{R}^{\prime} \mathrm{DAB}$ ) ${ }^{\circ+}$. We have calculated the structures of the model $\mathrm{N}$ - and $\mathrm{C}$-alkylated organozinc radical cations $[\mathrm{MeZn}(\mathrm{H}(\mathrm{Me}) \mathrm{NCH}=\mathrm{CHNH})]^{{ }^{+}+}$and $[\mathrm{MeZn}(\mathrm{HNC}(\mathrm{Me})-$ $\mathrm{HCH}=\mathrm{NH})]^{\circ+}$, respectively. The bond distances and angles of these species are listed in Table 3, together with 
Table 3. Hartree-Fock Optimized Internal Coordinates of the Neutral and Cationic $\mathrm{N}$ - and C-Alkylated Species

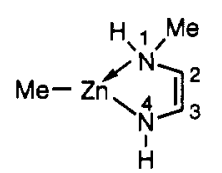

$\mathrm{N}$-alkylated product

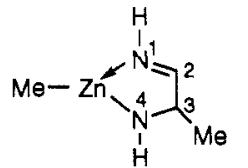

C-alkylated product

\begin{tabular}{|c|c|c|c|c|c|c|c|}
\hline complex & $\mathrm{Me}-\mathrm{Zn}$ & $\mathrm{Zn}-\mathrm{N} 1$ & $\mathrm{Zn}-\mathrm{N} 4$ & $\mathrm{~N} 1-\mathrm{C}_{2}$ & N4-C3 & $\mathrm{C} 2-\mathrm{C} 3$ & $\angle \mathrm{N}-\mathrm{Zn}-\mathrm{N}$ \\
\hline N-alkylated (neutral) & 1.96 & 2.24 & 1.88 & 1.47 & 1.36 & 1.35 & 84 \\
\hline N-alkylated (radical cation) & 1.97 & 2.17 & 2.06 & 1.43 & 1.32 & 1.39 & 80 \\
\hline C-alkylated (neutral) & 1.95 & 2.15 & 1.86 & 1.44 & 1.27 & 1.53 & 82 \\
\hline C-alkylated (radical cation) & 1.97 & 2.06 & 2.13 & 1.45 & 1.26 & 1.50 & 77 \\
\hline
\end{tabular}

a Bond lengths in ångstroms and bond angles in degrees.

those of the corresponding neutral alkylated organozine complexes.

It appears that the removal of one electron from the neutral alkylated organozinc species especially affects the $\mathrm{Zn}-\mathrm{N}$ bond lengths; i.e. in the $\mathrm{N}$-alkylated organozinc radical cation the amido $\mathrm{N}-\mathrm{Zn}$ bond is weakened, whereas the amino $\mathrm{N}-\mathrm{Zn}$ bond is strengthened. The same trend was observed in the $\mathrm{C}$-alkylated radical cation, in which the amido $\mathrm{Zn}-\mathrm{N}$ bond is weakened and the imino $\mathrm{Zn}-\mathrm{N}$ bond is strengthened relative to those in the neutral complex. The changes in distances upon ionization agree with the character of the HOMO in the neutral species. ${ }^{4}$

$[\mathrm{RZn}(t-\mathrm{BuDAB})]_{3} \mathrm{SCF}_{3}(\mathrm{R}=\mathrm{Me}(9), 2,6-\mathrm{Xylyl}$ (10)) in Solution. The cationic organozinc complexes 9 and 10 were studied in solution by ${ }^{19} \mathrm{~F}$ NMR spectroscopy in benzene and tetrahydrofuran. The ${ }^{19} \mathrm{~F}$ NMR spectra showed only one singlet resonance with chemical shift values in benzene (ppm relative to $\mathrm{CFCl}_{3}$ ) of $\delta-78.10$ (9) and $\delta-78.45(10)$ and in THF of $\delta-73.42(9)$ and $\delta-79.51$ (10), which are within the range characteristic for a noncoordinating $\mathrm{CF}_{3} \mathrm{SO}_{3}{ }^{-}$anion. ${ }^{11}$ Thus, in solution 9 dissociates to the cationic organozinc species [MeZn(t$\mathrm{BuDAB})]^{+}$(with a structure probably similar to that of the calculated model compound $\left.[\mathrm{MeZn}(\mathrm{HDAB})]^{+}\right)$and the $\mathrm{CF}_{3} \mathrm{SO}_{3}$ - anion.

Complex 9 reacts quantitatively with 1 -(trimethylsiloxy)-1-ethoxycyclopropane in a 1:1 molar ratio in tetrahydrofuran at $65^{\circ} \mathrm{C}$ in $12 \mathrm{~h}$ to form the 2-pyrrolidinone derivative 11 (coordinated to $\mathrm{MeZnOEt}$ ) and $\mathrm{Me}_{3} \mathrm{SiOTf}$. Hydrolysis of this coordination complex yields the organic heterocycle. The 2-pyrrolidinone compound 11 is the result of C-alkylation of the NCCN skeleton by $\left[\mathrm{CH}_{2^{-}}\right.$ $\mathrm{CH}_{2} \mathrm{COOEt}$ )- (formed by elimination of $\mathrm{Me}_{3} \mathrm{Si}^{+}$), and this species then undergoes elimination of the ethoxide group and ring closure (see Scheme 2). Recently an independent synthesis of 11 , involving the in situ reaction of 1-(trimethylsiloxy)-1-ethoxycyclopropane with 1 equiv of $\mathrm{ZnCl}_{2}$, was achieved. The $\mathrm{Zn}\left(\mathrm{CH}_{2} \mathrm{CH}_{2} \mathrm{COOEt}\right)_{2} / \mathrm{ZnCl}_{2}$ intermediate reacts further with $t$-BuDAB via $\mathrm{C}$-alkylation to afford $11 .{ }^{12} \mathrm{It}$ is interesting to recall that pure $\mathrm{Zn}\left(\mathrm{CH}_{2}-\right.$ $\left.\mathrm{CH}_{2} \mathrm{COOEt}\right)_{2}$ reacts with $t-\mathrm{BuDAB}$ in a $1: 1$ ratio to give the 3-pyrrolidinone 12 (see Scheme 2). ${ }^{12}$

(11) See also: (a) van Stein, G. C.; van Koten, G.; Vrieze, K.; Brévard, C.; Spek, A. L. J. Am. Chem. Soc. 1984, 106, 4486. (b) van Stein, G. C.; van Koten, G.; Vrieze, K.; Brévard, C. Inorg. Chem. 1984, 23, 4269. (c) van Stein, G. C.; van Koten, G.; De Bok, B.; Taylor, L. C.; Vrieze, K.; Brévard, C. Inorg. Chim. Acta 1984, 89, 29. (d) Modder, J. F.; de KlerkEngels, B.; Ankersmit, H. A.; Vrieze, K.; van Koten, G. New J. Chem. 1991, 15, 919. (e) Modder, J. F.; Vrieze, K.; Spek, A. L.; Challa, G.; van Koten, G. Inorg. Chem. 1992, $31,1238$.

(12) Wissing, E.; Kleijn, H.: Boersma, J.; van Koten, G. Recl. Trav. Chim. Pays-Bas 1993, 112, 618.

\section{Discussion}

While calculations on the model anionic complex [MeZn(HDAB $)]^{+}$indicate a planar structure, the coordination of the trifluormethanesulfonate group in 9 forces the methyl group out of the $\mathrm{Zn}-\mathrm{DAB}$ plane, leading to a $\mathrm{Me}-$ $\mathrm{Zn}-\mathrm{DAB}$ torsion angle of $130.4^{\circ}$. This suggests considerable interaction between the $[\mathrm{MeZn}(t-\mathrm{BuDAB})]^{+}$cation and the trifluormethanesulfonate anion. On the other hand, the fact that the $\mathrm{Zn}-\mathrm{O}$ bond is nearly perpendicular to the $\mathrm{Zn}-\mathrm{DAB}$ plane points to a rather ionic nature of this interaction.

Many examples of organometallic complexes with monodentate-bound triflate anions are known, and these all show a conformation of the triflate group similar to that found in 9.13 Although the structure of 9 is relatively simple, it has many aspects that make it worthwhile to compare its structural features with those of other $R_{2}$ $\mathrm{Zn}$ (diimine) complexes and organozinc alkoxides (see Table 4). The latter complexes are used as a model for 9 , because they can assist in evaluating the nature of the $\mathrm{Zn---OTf}$ interaction. The data in Table 4 support that substantial interaction between the OTf $\mathrm{f}^{-}$anion and the $[\mathrm{MeZn}(t-\mathrm{BuDAB})]^{+}$cation exists. This appears from the difference in both the $\mathrm{Zn}-\mathrm{N}$ and $\mathrm{Zn}-\mathrm{O}$ bond distances as well as the $\mathrm{C}-\mathrm{Zn}-\mathrm{O}$ angle of 9 and the model compounds in Table 4. The $\mathrm{Zn}-\mathrm{O}$ bond distance of 2.089(4) $\AA$ in 9 is comparable with those found in tetrameric [MeZnOMe $]_{4}$ (13) (average 2.08 $\AA$ ) $^{14}$ but substantially longer than these bonds in most other known zinc alkoxides (see 14; Table 4). This means that the OTf- anion in 9 binds more weakly than normal alkoxy anions. The $\mathrm{Zn}-\mathrm{C}$ bond length is normal for organozinc alkoxides, but the influence of the weaker binding of the triflate anion is shown from the

(13) (a) Lawrance, G. A. Chem. Rev, 1986, 86, 17. (b) Molybdenum: Cotton, F. A.; Reid, A. H.; Schwotzer, W. Inorg. Chem. 1985, 24, 3965. (c) Mercury: Balch, A. L.; Olmstead, M. M.; Rowley, S. P. Inorg. Chem. 1988, 27, 2275. (d) Silver: Richmond, T. G.; Kelson, E. P.; Arif, A. M. J. Am. Chem. Soc. 1988, 110, 2334. (e) Lanthanum: Smith, P. H.; Raymond, K. N. Inorg. Chem. 1985, 24, 3469. (f) Tantalum: Bianconi, P. A.; Vrtis, R. N.; Williams, I. D.; Engeler, M. P.; Lippard, S. J. Organometallics 1987, 6, 1968. (g) Cobalt: Dixon, N. E.; Jackson, W. G.; Lancaster, M. J.; Lawrance, G. A.; Sargeson, A. M. Inorg. Chem. 1981, 20, 470. (h) Iron: Humphrey, M. B.; Lamanna, W. M.; Brookhart, M.; Husk, G. R. Inorg. Chem. 1983, 22, 3355. (i) Ruthenium: Kraakman, M. J. A.; de Klerk-Engels, B.; de Lange, P. P. M.; Smeets, W. J. J.; Spek, A. L.; Vrieze, K. Organometallics 1992, 11, 3774. (j) Palladium: Anderson, O. P.; Packard, A. B. Inorg. Chem. 1979, 18, 1129.

(14) Shearer, H. M. M.; Spencer, C. B. Acta Crystallogr. 1990, B36, 2046 .

(15) (a) Corey, E. J.; Yuen, P.-W.; Hannon, F. J.; Wierda, D. A. J. Org. Chem. 1990, 55, 784. (b) The monomeric alkylzinc alkoxide 14 has to our knowledge the only other organozinc alkoxide structure with two nitrogen donor atoms bonded to zinc. However, the presence of the asymmetric monoanionic terdentate ligand in 14, which enforces a strained coordination geometry about zinc, makes a meaningful comparison with 9 not possible. 
Scheme 2

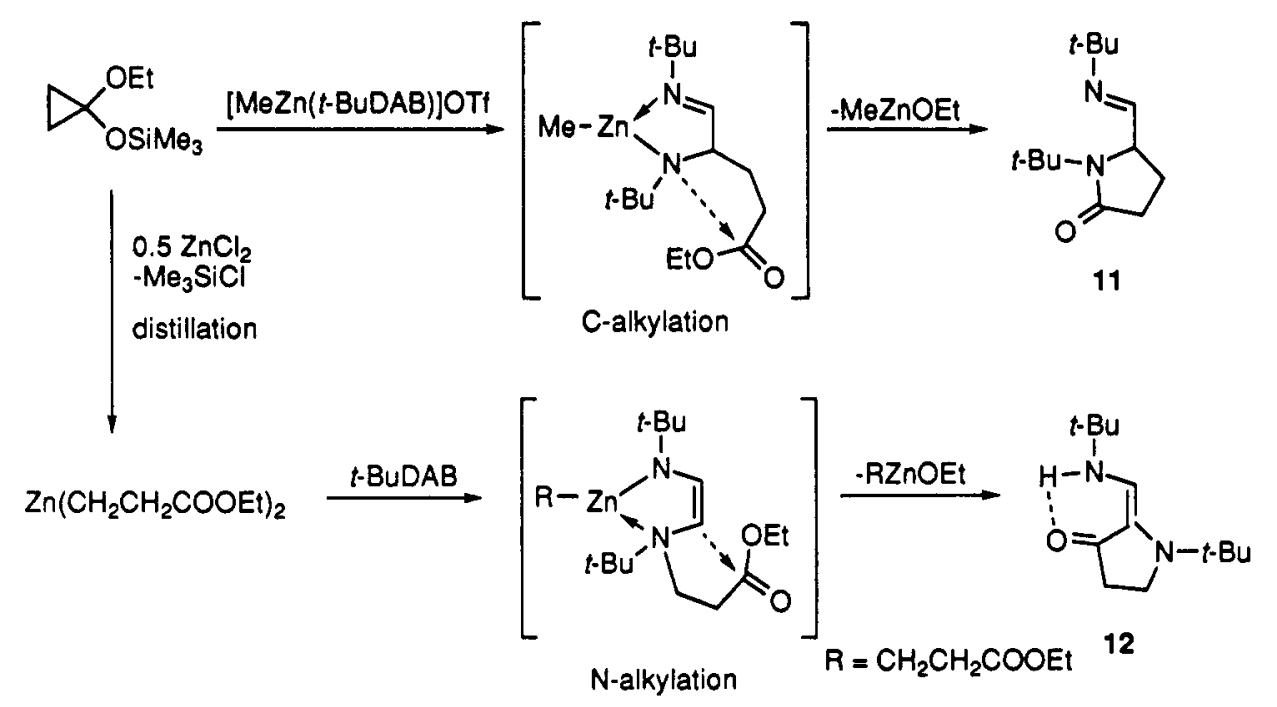

Table 4. Relevant Bond Lengths of Alkylzinc Alkoxide and Dialkylzinc Diimine Complexes

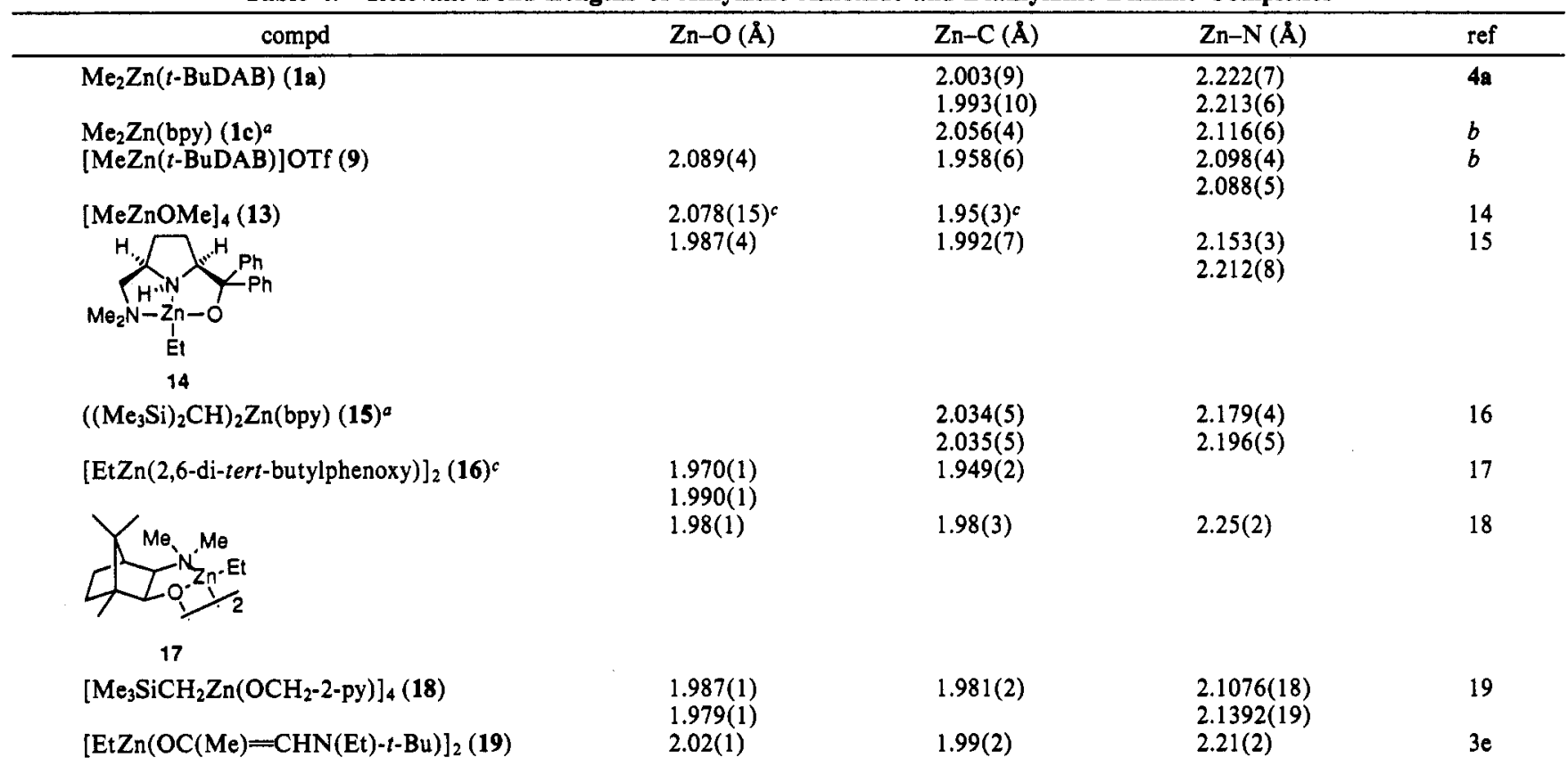

${ }^{a}$ bpy $=2,2^{\prime}$-bipyridine. ${ }^{b}$ This paper. ${ }^{c}$ Average bond length.

short $\mathrm{Zn}-\mathrm{N}$ bond lengths in 9 as compared to those found in $\mathrm{Me}_{2} \mathrm{Zn}(t-\mathrm{BuDAB})(1 \mathrm{a}),{ }^{4}$ in $\mathrm{Me}_{2} \mathrm{Zn}$ (bpy) (1c), and in the recently reported $\left(\left(\mathrm{Me}_{3} \mathrm{Si}\right)_{2} \mathrm{CH}\right)_{2} \mathrm{Zn}$ (bpy) (15). ${ }^{16}$

We suggest that for both 9 and 10 in solution a dissociation of the triflate-zinc bond takes place, leading to planar cationic three-coordinate zinc species $[\mathrm{RZn}(t-$ $\mathrm{BuDAB})]^{+}(\mathrm{R}=\mathrm{Me}, 2,6-\mathrm{xylyl})$ similar to the calculated model species [MeZn(HDAB)] ${ }^{+}$. This is in accord with the ${ }^{19} \mathrm{~F}$ NMR data, which show chemical shifts between $\delta-73$ and -79.5 ppm characteristic for a noncoordinating $\mathrm{CF}_{3} \mathrm{SO}_{3}$ - anion. 11

In the reaction of 1-(trimethylsiloxy)-1-ethoxycyclopropane with 9 it is most probably the dissociated OTf

(16) Westerhausen, M.; Rademacher, B.; Schwartz, W. J. Organomet. Chem. 1992, 427, 275.

(17) BergStresser, G. M. S. Ph.D. Dissertation, The Pennsylvania State University, 1986.

(18) Kitamura, M.; Okada, S.; Suga, S.; Noyori, R. J. Am. Chem. Soc. $1989,111,4028$.

(19) van der Schaaf, P. A.; Wissing, E.; Boersma, J.; Smeets, W. J. J.; Spek, A. L.; van Koten, G. Organometallics 1993, 12, 3624. anion and organozinc cation $[\mathrm{MeZn}(t-\mathrm{BuDAB})]^{+}$that are the reactive species. The OTf anion attacks the trimethylsilyl group of the cyclopropane derivative, and this results in the formation of $\mathrm{Me}_{3} \mathrm{SiOTf}$ and ring opening to $\left[\mathrm{CH}_{2} \mathrm{CH}_{2} \mathrm{COOEt}\right]^{-}$(see Figure 2). This latter nucleophilic anion subsequently attacks one of the two imine carbon atoms of the NCCN skeleton in the cation $[\mathrm{MeZn}(t$ $\mathrm{BuDAB})^{+}$. This carbon alkylation is supported by the Reed/Weinhold ${ }^{20}$ natural population analysis in our computational study, which showed that the partial atomic charges on the NCCN skeleton of [MeZn(HDAB)] ${ }^{+}$are the lowest on the carbon atoms; this makes them the most sensitive for attack by nucleophilic reagents.

Combining the evidence presented here for the existence in solution of the organozinc cationic species [RZn$\left.\left(\mathrm{R}^{\prime} \mathrm{DAB}\right)\right]^{+}$with the recent detection of organozinc radical anionic species $\left[R_{2} \ln \left(R^{\prime} D A B\right)\right]^{*-}$, we have to consider the

(20) Reed, A. E.; Weinstock, R. B.; Weinhold, F. J. Chem. Phys. 1985, $83,735$. 


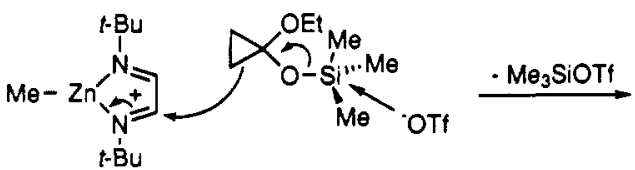<smiles></smiles>

Figure 2. Formation of the C-alkylated organozinc precursor complex for the 2-pyrrolidinone 11 via a nucleophilic attack of $\mathrm{OTf}^{-}$at the trimethylsilyl center.

possible roles these species could play in an alternative mechanism for the group transfer reaction of $R_{2} Z n$ with $\mathrm{R}^{\prime} \mathrm{DAB}$.

Alternative Mechanism 1. Obviously any mechanism has to start with the formation of the $1: 1$ coordination complex $R_{2} \mathrm{Zn}\left(\mathrm{R}^{\prime} \mathrm{DAB}\right)$. This was unambiguously established by NMR and UV-vis spectroscopic studies as well as by an X-ray crystal structure determination of $\mathrm{Me}_{2}-$ $\mathrm{Zn}\left(t\right.$-BuDAB). ${ }^{4}$ These complexes have only limited thermal stability, and when the temperature is raised above a critical temperature, an intramolecular SET occurs to give the radical pair $\left[R Z n\left(R^{\prime} D A B\right)\right]^{*} / R^{*}$ (see Scheme 1 and eq 3 ). From this stage on, an alternative mechanism

$$
\mathrm{R}_{2} \mathrm{Zn}\left(\mathrm{R}^{\prime} \mathrm{DAB}\right) \rightarrow\left[\mathrm{RZn}\left(\mathrm{R}^{\prime} \mathrm{DAB}\right)\right]^{*} / \mathrm{R}^{\bullet}
$$

$$
\begin{aligned}
& {\left[\mathrm{RZn}\left(\mathrm{R}^{\prime} \mathrm{DAB}\right)\right]^{\bullet}+\mathrm{R}_{2} \mathrm{Zn}\left(\mathrm{R}^{\prime} \mathrm{DAB}\right) \rightleftharpoons} \\
& {\left[\mathrm{RZn}^{\prime}\left(\mathrm{R}^{\prime} \mathrm{DAB}\right)\right]^{+}+\left[\mathrm{R}_{2} \mathrm{Zn}\left(\mathrm{R}^{\prime} \mathrm{DAB}\right)\right]^{\bullet-}}
\end{aligned}
$$

$$
\left[\mathrm{RZn}\left(\mathrm{R}^{\prime} \mathrm{DAB}\right)\right]^{+}+\mathrm{R}^{\bullet} \rightarrow \text { [alkylation products }^{\bullet+}
$$

$$
\begin{array}{r}
\text { [alkylation products }]^{\circ+}+\left[\mathrm{R}_{2} \mathrm{Zn}\left(\mathrm{R}^{\prime} \mathrm{DAB}\right)\right]^{--} \rightarrow \\
\text { alkylation products }+\mathrm{R}_{2} \mathrm{Zn}\left(\mathrm{R}^{\prime} \mathrm{DAB}\right)
\end{array}
$$

for that shown in Scheme 1 has to be considered. A main consideration is both the stability and the nature of the radical pair in the solvent cage. Scheme 1 is based on a fast collapse of the radical pair before radical separation takes place. The proposed alternative for this fast collapse assumes the formation of a steady-state concentration of the persistent organozinc radical pair $\left[R Z n\left(R^{\prime} D A B\right)\right] \%$ $R^{\bullet}$, which collapses in reaction with the initial $1: 1$ coordination complex $R_{2} \mathrm{Zn}\left(\mathrm{R}^{\prime} \mathrm{DAB}\right)$ to give the monoorganozinc cation $\left[R Z n\left(R^{\prime} D A B\right)\right]^{+}$and the radical anion $\left[R_{2} \operatorname{Zn}\left(R^{\prime} D A B\right)\right]^{--}$(see eq 4). Subsequent attack of the alkyl radical $R^{-}$at either the imine-N or $-C$ center of the cationic organozinc species $\left[R Z n\left(R^{\prime} D A B\right)\right]^{+}$has to occur to give the alkylated products as their radical cations (see eq 5). In a final SET from the radical anion to the alkylated cationic product, the neutral products and the $1: 1$ coordination complex are formed (see eq 6). For this proposal to be valid, all these steps would have to be faster than bimolecular processes involving the alkyl radical, e.g. proton abstraction, radical disproportionation, radical dimerization, or radical rearrangement. From the reaction of $t$-BuDAB with $\mathrm{Zn}\left(\mathrm{CH}_{2} \mathrm{CMe}_{2} \mathrm{Ph}\right)_{2}$ (=(neophyl) $2 \mathrm{Zn}$ ), wherein no neophyl rearrangement was observed (group rearrangement rate $\left.7 \times 10^{2} \mathrm{~s}^{-1}\right),{ }^{21-23}$ we estimate the rate of alkylation to be in the range $\left(7 \times 10^{4}\right)-\left(7 \times 10^{6}\right) \mathrm{s}^{-1}$, which must be faster than the rate of the aforementioned bimolecular side reactions.

The formation of the cationic and radical anionic intermediates (eq 4) can be considered in two different ways. First, it may be an oxidation reaction, in agreement with the low ionization potential $(6 \mathrm{eV})$ for the radical organozinc complexes $\left[R Z n\left(R^{\prime} D A B\right)\right] \cdot{ }^{24}$ Second, the reaction can be regarded as a dissociation reaction, which is supported by the observations of the groups of Richey and of Bickelhaupt, who recently showed similar reactions of $R_{2} \mathrm{Mg}$ and $R_{2} \mathrm{Zn}$ with crown ethers and cryptands (see eq 7$) .5 f, 7$

$$
2 \mathrm{MgR}_{2}+\text { cryptand } \rightleftharpoons \mathrm{RMg}(\text { cryptand })^{+}+\mathrm{R}_{3} \mathrm{Mg}^{-}
$$

The main difference between the alternative mechanism and the earlier one (Scheme 1) is that here the alkylation by the alkyl radical takes place at a cationic organozinc species. Although we have no accurate data for this homolytic $\mathrm{C}-\mathrm{C}$ or $\mathrm{C}-\mathrm{N}$ bond formation, this step seems less likely in view of the electrophilic nature of $R^{*}$ radicals. The final SET step between the product radical cation and the radical anion (eq 6), in which a primary coordination complex and a neutral alkylation product are reformed, is most probably endothermic.

In conclusion, this alternative mechanism has some major drawbacks, the most important one of which probably is the fact that the rate-determining intermolecular SET step cannot be correlated with the spectroscopic properties of the primary 1:1 $\mathrm{R}_{2} \mathrm{Zn}(t$-BuDAB) complexes (the HOMO-LUMO energy gap decreases in the series $\mathrm{R}=\mathrm{Me}>\mathrm{Et}>i-\mathrm{Pr}>t-\mathrm{Bu}$, whereas the reactivity increases in this order).

Alternative Mechanism 2. The radical anion observed in our reaction by ESR spectroscopy is $\left[R_{2} \mathrm{Zn}\left(\mathrm{R}^{\prime} \mathrm{DAB}\right)\right]^{--}$. It is likely that the $\left[R Z n\left(R^{\prime} D A B\right)\right]^{+}$cation is in close proximity to the radical anion and most likely forms an ion pair with it. (At the low concentrations of the ESR experiment this pair could be completely dissociated.) In this ion pair $\mathrm{R}^{-}$transfer from the radical anion to the activated NCCN skeleton in the cation would lead to formation of the alkylation product with concomitant formation of the $\left[\mathrm{RZn}\left(\mathrm{R}^{\prime} \mathrm{DAB}\right)\right]^{\bullet}$ radical.

$$
\begin{aligned}
& {\left[\mathrm{RZn}\left(\mathrm{R}^{\prime} \mathrm{DAB}\right)\right]^{+}+\left[\mathrm{R}_{2} \mathrm{Zn}\left(\mathrm{R}^{\prime} \mathrm{DAB}\right)\right]^{+-} \rightarrow} \\
& \text { alkylation product }+\left[\mathrm{RZn}\left(\mathrm{R}^{\prime} \mathrm{DAB}\right)\right]^{\bullet}
\end{aligned}
$$

Accordingly, the formation of a low steady-state concentration of $\left[R Z n\left(R^{\prime} D A B\right)\right]^{\bullet}$ would be sufficient to drive this process, as it would be catalytic in $\left[R Z n\left(R^{\prime} D A B\right)\right]^{\circ}$. This mechanism seems attractive, as in the [RZn$\left.\left(\mathrm{R}^{\prime} \mathrm{DAB}\right)\right]^{+}$cation the $\mathrm{N}=\mathrm{C}$ bonds are clearly more polarized (i.e. shortened $\mathrm{Zn}-\mathrm{N}$ and slightly elongated $\mathrm{N}=\mathrm{C}$ bonds). However, this mechanism fails to indicate why, depending on the nature of $\mathrm{R}^{\bullet}$, either selective $\mathrm{N}$ - or C-alkylation is obtained.

(21) The neophyl radical is known to rearrange to $\mathrm{PhCH}_{2} \mathrm{CMe}_{2}{ }^{\circ}$ via a 1,2-phenyl shift. 22 The rate of this rearrangement was found to be $k_{\mathrm{r}}$ $=762 \mathrm{~s}^{-1} \cdot{ }^{23}$

(22) Urry, W. H.; Kharasch, M. S. J. Am. Chem. Soc. 1944, 66, 1438.

(23) Lindsay, D. A.; Lusztyk, J.; Ingold, K. U. J. Am. Chem. Soc. 1984, $106,7087$.

(24) Louwen, J. N.; Stufkens, D. J.; Oskam, A. J. Chem. Soc., Dalton Trans. 1984, 2683. 


\section{Concluding Remarks}

The synthetic potential of the regioselective alkylation reaction of $R^{\prime} D A B$ by means of $R_{2} Z n$ compounds appears from the synthesis of not only imine-amines ${ }^{3 a-c}$ and organozinc-enamines ${ }^{3 a-c}$ but also $\beta$-lactams ${ }^{3 c-h}$ using this route. However, the mechanistic understanding is still less developed. The currently used working hypothesis involving the primary formation of a biradical intermediate (in a solvent cage or as a still highly bonded species) is in agreement with the observed product formation in these group-transfer reactions. The isolation of the organozinc(R'DAB) triflates 9 and 10 and the detection of the radical anion species $\left[\mathrm{R}_{2} \mathrm{Zn}(t-\mathrm{BuDAB})\right]^{*-}$ has shown that such species are stable and may exist in solutions of $R_{2} Z n$ with $\mathrm{R}^{\prime} \mathrm{DAB}$. As has become evident from the discussion in this paper, however, it does not lead to the formulation of an alternative mechanism based on these species as key intermediates. Further, recent studies of the mechanistic details of group transfer in organozinc 1,4-dihetero-1,3butadiene complexes have pointed to possible synthetic routes for the $\left[\mathrm{R}_{2} \mathrm{Zn}(t \text {-BuDAB) }]^{-\mathrm{-}}\right.$ radical anions..$^{10}$ Preliminary results show that these radical anions are prone to undergo a subsequent intramolecular SET leading partly to the formation of a mixture of $\mathrm{N}$ - and $\mathrm{C}$-alkylated products as well as to the formation of $\mathrm{RZn}\left(\mathrm{R}^{\prime} \mathrm{NCH}=\right.$ $\mathrm{CHNR}^{\prime}$ ) heterozincate anions. It is obvious that further conclusions on the nature of the biradical intermediate and possible species derived therefrom must await isolation and full characterization of the organozinc radical anions and novel heterozincates.

\section{Experimental Section}

General Data. All experiments were carried out under a dry and oxygen-free nitrogen atmosphere, using standard Schlenk techniques. Solvents were carefully dried and distilled from sodium/benzophenone prior to use. All starting chemicals were purchased from Aldrich Chemical Co. or Janssen Chimica. The starting materials 1,4-di-tert-butyl-1,4-diaza-1,3-butadiene ( $t$ $\mathrm{BuDAB}){ }^{25} \mathrm{Me}_{2} \mathrm{Zn}(t-\mathrm{BuDAB}){ }^{4}$ and 1-(trimethylsiloxy)-1-ethoxycyclopropane ${ }^{26}$ were prepared according to literature procedures. ${ }^{1} \mathrm{H},{ }^{13} \mathrm{C}$, and ${ }^{19} \mathrm{~F}$ NMR spectra were recorded on Bruker AC-100, AC-200, or AC-300 spectrometers. Elemental analyses were performed by Dornis und Kolbe, Mikroanalytisches Laboratorium, Mülheim a.d. Ruhr, Germany.

[MeZn(t-BuDAB)]OTf (9). A red solution of $\mathrm{Me}_{2} \mathrm{Zn}(t-$ $\mathrm{BuDAB})(2.63 \mathrm{~g}, 10 \mathrm{mmol})$ in $\mathrm{Et}_{2} \mathrm{O}(75 \mathrm{~mL})$ was added dropwise to a magnetically stirred solution of HOTf $(1.50 \mathrm{~g}, 10 \mathrm{mmol})$ in $\mathrm{Et}_{2} \mathrm{O}(50 \mathrm{~mL})$ at $0^{\circ} \mathrm{C}$. After the mixture was stirred for $10 \mathrm{~min}$ at room temperature, the solvent was removed in vacuo. The yellow residue was washed with hexane $(2 \times 25 \mathrm{~mL})$ and dried in vacuo, affording 9 as an off-white solid in $3.69 \mathrm{~g}(93 \%)$ yield. ${ }^{1} \mathrm{H}$ NMR $\left(200 \mathrm{MHz}, \mathrm{C}_{8} \mathrm{D}_{6}\right): \delta 7.47(\mathrm{~s}, 2 \mathrm{H}$, imine-H) $1.17(\mathrm{~s}, 18 \mathrm{H}$, $t$ - Bu), -0.15 (s, 3H, Me-Zn). ${ }^{13} \mathrm{C}$ NMR (50 MHz, $\left.\mathrm{C}_{6} \mathrm{D}_{6}\right): 155.4$ (imine-C), $121.8\left(\mathrm{CF}_{3}, \mathrm{q},{ }^{1} J(\mathrm{C}-\mathrm{F})=318.9 \mathrm{~Hz}\right), 61.0\left(\mathrm{C}_{\left(\mathrm{CH}_{3}\right)}\right)$, $29.2\left(\mathrm{C}\left(\mathrm{CH}_{3}\right)_{3}\right),-12.7\left(\mathrm{ZnCH}_{3}\right)$. ${ }^{19} \mathrm{~F}$ NMR $(100 \mathrm{MHz}):-78.09$ (in $\mathrm{C}_{6} \mathrm{D}_{6}$ ), -73.42 (in THF-d $d_{8}$ ). Anal. Calcd for $\mathrm{C}_{12} \mathrm{H}_{23} \mathrm{~N}_{2} \mathrm{O}_{3} \mathrm{SF}_{3} \mathrm{Zn}$ : $\mathrm{C}, 36.24 ; \mathrm{H}, 5.83 ; \mathrm{N}, 7.04$. Found: C, 36.60; $\mathrm{H}, 5.68 ; \mathrm{N}, 6.95$.

[(2,6-xylyl) Zn(t-BuDAB)]OTf (10). To a yellow solution

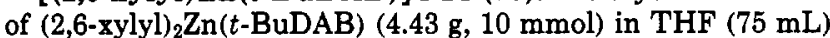
at $0^{\circ} \mathrm{C}$ was added dropwise a solution of HOTf $(1.5 \mathrm{~g}, 10 \mathrm{mmol})$ in THF $(10 \mathrm{~mL})$. After the mixture was stirred for $10 \mathrm{~min}$ at room temperature, the solvent was removed in vacuo, leaving a white residue. This residue was washed with hexanes $(2 \times 25$ $\mathrm{mL}$ ) and dried in vacuo, affording 10 as a white solid in $4.63 \mathrm{~g}$ (95\%) yield. ${ }^{1} \mathrm{H}$ NMR (200 MHz, $\left.\mathrm{C}_{6} \mathrm{D}_{6}\right): \delta 7.20-7.09(\mathrm{~m}, 3 \mathrm{H}$,

(25) Kliegman, J. M.; Barnes, R. K. Tetrahedron 1970, 62, 2555.

(26) Nakamura, E.; Kuwajima, I. Org. Synth. 1988, 66, 43. aryl), 7.08 (s, 2H, imine-H), 2.43 (s, 6H, Me xylyl), 1.09 (s, 18H, $t$-Bu). ${ }^{13} \mathrm{C} \mathrm{NMR}\left(50 \mathrm{MHz}, \mathrm{C}_{6} \mathrm{D}_{6}\right): \delta 155.2$ (imine-C), 151.9, 145.3, $126.8,124.9$ (aryl), $120.6\left(\mathrm{CF}_{3}, \mathrm{q},{ }^{1} J(\mathrm{C}-\mathrm{F})=346.6 \mathrm{~Hz}\right), 60.9$ $\left(\mathrm{C}\left(\mathrm{CH}_{3}\right)\right), 29.0\left(\mathrm{C}\left(\mathrm{CH}_{3}\right)_{3}\right), 26.7$ (Me xylyl). ${ }^{19} \mathrm{~F}$ NMR $(100 \mathrm{MHz})$ : -78.49 (in $\mathrm{C}_{6} \mathrm{D}_{6}$ ), -79.51 (in THF- $d_{8}$ ). Anal. Calcd for $\mathrm{C}_{19-}$ $\mathrm{H}_{29} \mathrm{~N}_{2} \mathrm{O}_{3} \mathrm{SF}_{3} \mathrm{Zn}: \mathrm{C}, 46.78 ; \mathrm{H}, 5.99 ; \mathrm{N}, 5.74$. Found: $\mathrm{C}, 46.71 ; \mathrm{H}$, $5.95 ; \mathrm{N}, 5.69$.

1-tert-Butyl-5-((tert-butylimino)methyl)-2-pyrrolidinone (11). A mixture of [MeZn( $t-B u D A B)] O T f(3.97 \mathrm{~g}, 10 \mathrm{mmol})$ and 1-(trimethylsiloxy)-1-ethoxycyclopropane $(1.74 \mathrm{~g}, 10 \mathrm{mmol})$ in THF ( $50 \mathrm{~mL}$ ) was heated for $12 \mathrm{~h}$ at $65^{\circ} \mathrm{C}$. The solvent was evaporated in vacuo, and hexane $(50 \mathrm{~mL})$ was then added. The resulting mixture was quenched with a saturated aqueous $\mathrm{NH}_{4}$ Cl solution $(30 \mathrm{~mL})$. The water layer was separated and extracted twice with $\mathrm{Et}_{2} \mathrm{O} /$ pentane $(80 / 20)(30 \mathrm{~mL})$. The combined organic layers were dried $\left(\mathrm{MgSO}_{4}\right)$ and concentrated in vacuo, to afford $11\left(89 \%\right.$ yield) as a dark yellow solid. ${ }^{1} \mathrm{H}$ NMR $\left(\mathrm{C}_{6} \mathrm{D}_{6}\right): \delta 7.28$ (d, $J=6.2 \mathrm{~Hz}, 1 \mathrm{H}, \mathrm{N}=\mathrm{CH}), 4.09(\mathrm{~m}, J=8.5 \mathrm{~Hz}, J=6.2 \mathrm{~Hz}, J$ $=1.4 \mathrm{~Hz}, 1 \mathrm{H}, \mathrm{N}=\mathrm{C}-\mathrm{CH}), 2.29-1.94\left(\mathrm{~m}, 2 \mathrm{H}, \mathrm{CH}_{2}-\mathrm{C}=0\right), 1.76-$ $1.52\left(\mathrm{~m}, 1 \mathrm{H}, \mathrm{CHH}-\mathrm{CH}_{2} \mathrm{C}=0\right), 1.41\left(\mathrm{~s}, 9 \mathrm{H}, \mathrm{C}\left(\mathrm{CH}_{3}\right)_{3}\right), 1.35-1.09$ (m, $\left.1 \mathrm{H}, \mathrm{CH} \mathrm{H}^{\prime}-\mathrm{CH}_{2} \mathrm{C}=0\right), 1.04\left(\mathrm{~s}, 9 \mathrm{H}, \mathrm{C}\left(\mathrm{CH}_{3}\right)_{3}\right)$. ${ }^{13} \mathrm{C} \mathrm{NMR}$ $\left(\mathrm{C}_{6} \mathrm{D}_{6}\right): \delta 174.5(\mathrm{C}=0), 158.3(\mathrm{~N}=\mathrm{CH}), 62.3(\mathrm{~N}-\mathrm{CH}), 56.7,54.3$

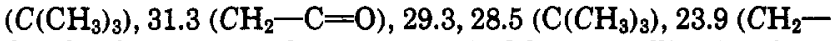
$\mathrm{CH}_{2} \mathrm{C}=0$ ). The product was purified by crystallization from pentane at $-78^{\circ} \mathrm{C}$. Mp: $40^{\circ} \mathrm{C}$. IR $(\mathrm{KBr}): 1685 \mathrm{~cm}^{-1}(\nu(\mathrm{C}=0))$. These data are similar to those of an authentic sample of $10 \mathrm{~b}$ prepared by an independent route. ${ }^{12}$

Computational Details. Hartree-Fock calculations have been performed with the Gaussian 90 program..$^{27}$ The organozinc cation $[\mathrm{MeZn}(\mathrm{HDAB})]^{+}$has been fully optimized under the restriction of $C_{8}$ symmetry. No symmetry restrictions have been applied to the radical cation species. Open shells were treated within the UKF scheme. Pseudopotentials and DZ valence basis sets (including polarization functions for zinc) are those used in our previous study.

X-ray Structure Determination of 1c. X-ray data were collected at $295 \mathrm{~K}$ on an Enraf-Nonius CAD4 diffractometer for a colorless block-shaped crystal sealed in a Lindemann glass capillary. Unit cell parameters were derived from the setting angles of 25 SET4 reflections in the range $7^{\circ}<\theta<15^{\circ}$. Diffraction was poor at higher diffraction angles, indicative of disorder. Data were corrected for Lp. No decay during data collection was observed. Observed systematic extinctions are consistent with space groups $P b a 2$ and Pbam. A preliminary structure determination (DIRDIF 92) ${ }^{28}$ was done in the noncentrosymmetric space group $P b a 2$. A subsequent difference density map showed a large peak $1.8 \AA$ from the zinc. This was taken as indicative for the presence of a statistical inversion center halfway, leading to a disordered structure in space group Pbam. Subsequent full-matrix least-squares refinement with SHELXL93 ${ }^{29}$ converged at $R_{1}=0.046\left(w R_{2}=0.127\right)$. Hydrogen atoms were taken into account at calculated positions and refined riding on their carrier atom. Scattering factors were taken from ref 30 and corrected for anomalous dispersion. ${ }^{31}$ Geometrical calculations and the ORTEP illustration were done with PLATON. ${ }^{32}$

Crystal data and numerical details of the structure determinations of $1 \mathrm{c}$ and 9 are given in Table 5. Final atomic coordinates and equivalent isotropic parameters of the non-hydrogen atoms for 1c are given in Table 6 .

(27) Frisch, M. J.; Head-Gordon, M.; Trucks, G. W.; Foresman, J. B.; Schlegel, H. B.; Raghavachari, K.; Robb, M.; Binkley, J. S.; Gonzalez, C.; DeFrees, D. J.; Fox, D. J.; Whiteside, R. A.; Seeger, R.; Melius, C. F.; Baker, J.; Kahn, L. R.; Stewart, J. J. P.; Topiol, S.; Pople, J. A. Gaussian 90, Revision F; Gaussian, Inc., Pittsburgh, PA, 1990.

(28) Beurskens, P. T.; Admiraal, G.; Beurskens, G.; Bosman, W. P.; Garcia-Granda, S.; Gould, R. O. The DIRDIF Program System; Technical Report of the Crystallographic Laboratory; University of Nijmegen: Nijmegen, The Netherlands, 1992.

(29) Sheldrick, G. M. SHELXL-93, Crystal Structure Refinement Package; University of Göttingen, Göttingen, Germany, 1993.

(30) Cromer, D. T.; Mann, J. B. Acta Crystallogr. 1968, A24, 321.

(31) Cromer, D. T.; Liberman, D. J. Chem. Phys. 1970, 53, 1891.

(32) Spek, A. L. Acta Crystallogr. 1990, C34, 46. 
Table 5. Crystal Data and Numerical Details of the Structure Determinations of $1 \mathrm{c}$ and 9

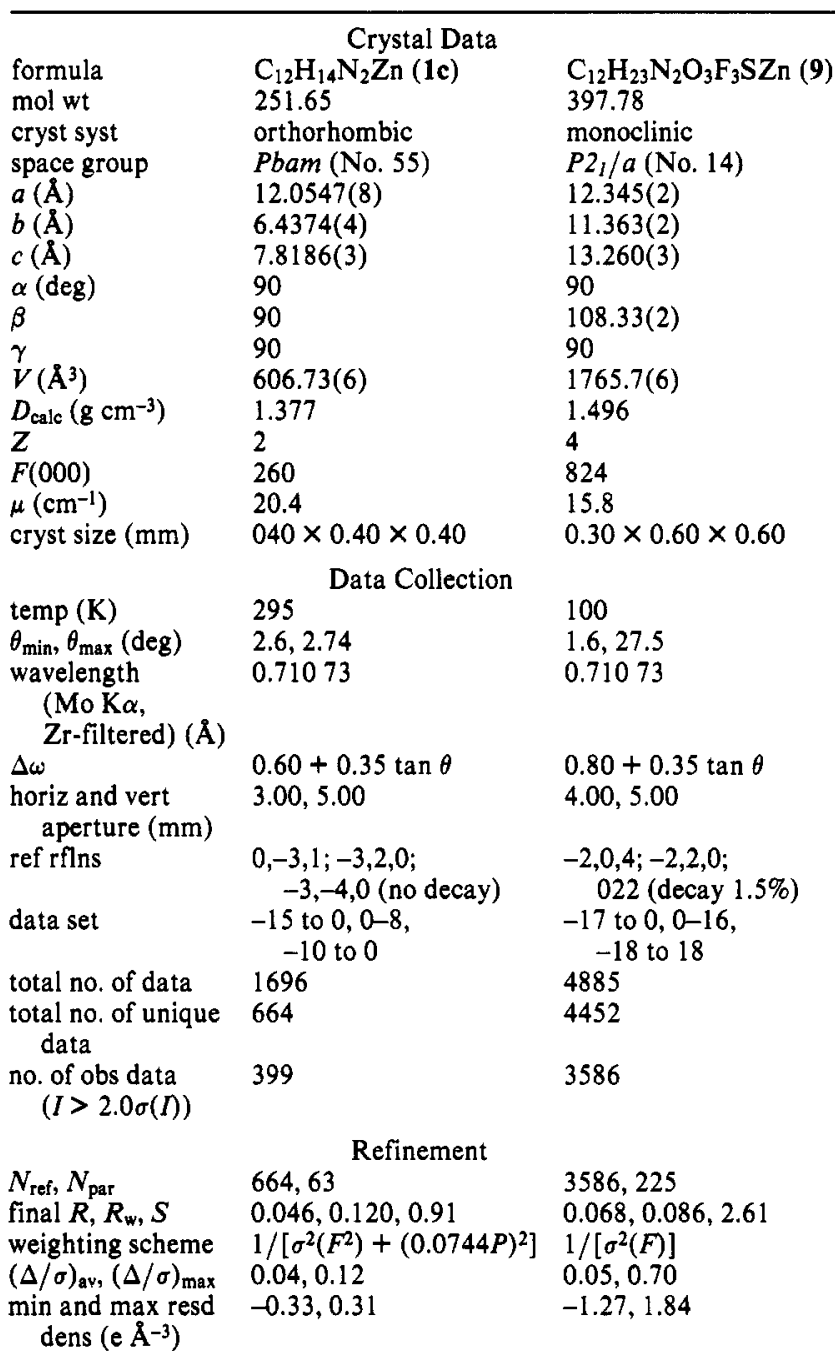

Table 6. Final Coordinates and Equivalent Isotropic Thermal Parameters of the Non-Hydrogen Atoms for 1c

\begin{tabular}{lllll}
\hline atom & \multicolumn{1}{c}{$x$} & \multicolumn{1}{c}{$y$} & \multicolumn{1}{c}{$z$} & $U(\mathrm{eq})\left(\AA^{2}\right)^{a}$ \\
\hline${ }^{*} \mathrm{Zn}{ }^{b}$ & 0 & 0 & $0.11537(11)$ & $0.0519(3)$ \\
$* \mathrm{~N}(1)$ & $0.0596(11)$ & $0.1642(16)$ & $0.3311(9)$ & $0.030(2)$ \\
$\mathrm{C}(1)$ & $0.0341(3)$ & $0.0941(6)$ & $1 / 2$ & $0.0373(12)$ \\
$* \mathrm{C}(2)$ & $0.0727(13)$ & $0.205(2)$ & $0.6295(14)$ & $0.041(3)$ \\
${ }^{*} \mathrm{C}(3)$ & $0.129(3)$ & $0.382(4)$ & $0.627(3)$ & $0.080(11)$ \\
${ }^{*} \mathrm{C}(4)$ & $0.1578(9)$ & $0.446(2)$ & $0.472(4)$ & $0.069(10)$ \\
${ }^{*} \mathrm{C}(5)$ & $0.125(3)$ & $0.344(4)$ & $0.333(4)$ & $0.050(4)$ \\
$\mathrm{C}(6)$ & $-0.1241(4)$ & $0.1685(9)$ & 0 & $0.092(3)$
\end{tabular}

${ }^{a} \mathrm{U}(\mathrm{eq})=$ one-third of the trace of the orthogonalized $U .{ }^{b}$ Starred atom sites have a population less than 1.0.

X-ray Structure Determination of 9. Crystal data and numerical details of the structure determination are given in Table 5. A crystal suitable for data collection was sampled in
Table 7. Final Coordinates and Equivalent Isotropic Thermal Parameters of the Non-Hydrogen Atoms for 9

\begin{tabular}{llrll}
\hline atom & \multicolumn{1}{c}{$x$} & \multicolumn{1}{c}{$y$} & \multicolumn{1}{c}{$z$} & $U(e q)\left(\AA^{2}\right)^{a}$ \\
\hline $\mathrm{Zn}$ & $0.57716(5)$ & $0.14907(5)$ & $0.25069(5)$ & $0.0162(2)$ \\
$\mathrm{S}$ & $0.33410(12)$ & $0.02958(12)$ & $0.19591(10)$ & $0.0203(4)$ \\
$\mathrm{F}(1)$ & $0.3753(4)$ & $0.0539(4)$ & $0.3997(3)$ & $0.0574(16)$ \\
$\mathrm{F}(2)$ & $0.2117(4)$ & $-0.0226(4)$ & $0.3162(3)$ & $0.0493(16)$ \\
$\mathrm{F}(3)$ & $0.3639(4)$ & $-0.1244(4)$ & $0.3474(4)$ & $0.0577(16)$ \\
$\mathrm{O}(1)$ & $0.2966(4)$ & $0.1496(4)$ & $0.1860(4)$ & $0.0355(14)$ \\
$\mathrm{O}(2)$ & $0.4563(3)$ & $0.0142(3)$ & $0.2087(3)$ & $0.0203(11)$ \\
$\mathrm{O}(3)$ & $0.2638(3)$ & $-0.0519(4)$ & $0.1219(3)$ & $0.0388(14)$ \\
$\mathrm{N}(1)$ & $0.5889(4)$ & $0.1787(3)$ & $0.0983(3)$ & $0.0149(12)$ \\
$\mathrm{N}(2)$ & $0.7180(4)$ & $0.0443(4)$ & $0.2566(3)$ & $0.0153(12)$ \\
$\mathrm{C}(1)$ & $0.5124(4)$ & $0.2560(4)$ & $0.0148(4)$ & $0.0167(14)$ \\
$\mathrm{C}(2)$ & $0.5697(5)$ & $0.3026(5)$ & $-0.0643(4)$ & $0.0221(17)$ \\
$\mathrm{C}(3)$ & $0.4791(5)$ & $0.3578(5)$ & $0.0736(4)$ & $0.0233(17)$ \\
$\mathrm{C}(4)$ & $0.4080(5)$ & $0.1810(5)$ & $-0.0439(4)$ & $0.0250(17)$ \\
$\mathrm{C}(5)$ & $0.6775(5)$ & $0.1317(4)$ & $0.0878(4)$ & $0.0183(16)$ \\
$\mathrm{C}(6)$ & $0.7474(5)$ & $0.0550(5)$ & $0.1734(4)$ & $0.0196(17)$ \\
$\mathrm{C}(7)$ & $0.7830(4)$ & $-0.0310(5)$ & $0.3486(4)$ & $0.0187(14)$ \\
$\mathrm{C}(8)$ & $0.8837(5)$ & $-0.0939(6)$ & $0.3289(5)$ & $0.0274(17)$ \\
$\mathrm{C}(9)$ & $0.8229(5)$ & $0.0511(5)$ & $0.4435(4)$ & $0.0271(17)$ \\
$\mathrm{C}(10)$ & $0.6971(5)$ & $-0.1202(5)$ & $0.3645(5)$ & $0.0259(17)$ \\
$\mathrm{C}(11)$ & $0.5636(6)$ & $0.2605(5)$ & $0.3587(5)$ & $0.0318(19)$ \\
$\mathrm{C}(12)$ & $0.3225(6)$ & $-0.0184(5)$ & $0.3233(5)$ & $0.0278(17)$
\end{tabular}

${ }^{a} U(\mathrm{eq})=$ one-third of the trace of the orthogonalized $\mathbf{U}$.

paraffin oil and transferred into a cold nitrogen stream. Data were collected on an Enraf-Nonius CAD4 diffractometer. Data were corrected for $\mathrm{Lp}$ and a small linear decay during data collection $(1.5 \%)$. The structure was solved by direct methods (SHELXS-86) ${ }^{33}$ and refined by full-matrix least-squares techniques (SHELX-76) ${ }^{34}$ to $R=0.068$. Hydrogen atoms were taken into account at calculated positions and refined riding on their carrier atom. Scattering factors were taken from Cromer and $\mathrm{Mann}^{30}$ and corrected for anomalous dispersion. ${ }^{31}$ Geometrical calculations and the ORTEP illustration were done with the program PLATON. ${ }^{32}$ Final atomic coordinates and equivalent isotropic parameters of the non-hydrogen atoms for 9 are given in Table 7.

Acknowledgment. This work was supported in part (E.W. and A.L.S.) by the Netherlands Foundation for Chemical Research (SON) with financial aid from the Netherlands Organisation for Advancement of Pure Research (NWO). We thank Prof. F. Bickelhaupt for helpful discussions, Mr. J.-M. Ernsting for carrying out the ${ }^{19} \mathrm{~F}$ NMR experiments, and Mr. A. J. M. Duisenberg for collecting the X-ray data.

Supplementary Material Available: Tables of anisotropic thermal parameters, all $\mathrm{H}$-atom parameters, and bond lengths and bond angles for $1 c$ and 9 (13 pages). Ordering information is given on any current masthead page.

OM9401061

(33) Sheldrick, G. M. SHELXS-86, Program for Crystal Structure Determination; University of Göttingen, Göttingen, Germany, 1986.

(34) Sheldrick, G. M. SHEL X-76, Crystal Structure Analysis Package; University of Cambridge, Cambridge, England, 1976. 